\title{
Attitudes toward Intimate Partner Violence and Intimate Partner Acceptance-Rejection among Cape Verdean students living in Portugal
}

\author{
Sofia Neves 1, 2, *, Márcia Machado², Francisco Machado², \& Fábia Pinheiro ${ }^{3}$ \\ ${ }^{1}$ CIEG - Instituto Superior de Ciências Sociais e Políticas, Lisboa, Portugal \\ ${ }^{2}$ Instituto Universitário da Maia, Maia, Portugal \\ ${ }^{3}$ União de Mulheres Alternativa e Resposta, Lisboa, Portugal
}

\begin{abstract}
This research sought to determine the prevalence of intimate partner violence, characterize attitudes toward violence, analyse relations between perceptions of intimate partner acceptance-rejection and practices of violence and examine relations between intimate partner acceptance-rejection and beliefs and attitudes toward intimate partner violence among Cape Verdean students that lives in Portugal. One hundred and sixteen participants, aged 15 to 25 years, from three professional schools, four secondary schools and one university, completed the Scale of Beliefs about Marital Violence, Marital Violence Inventory, Dating Violence Scales and Intimate Partner Acceptance-Rejection Questionnaire. Significant positive correlations were found between beliefs about marital violence, dating violence attitudes and intimate partner rejection. Regressions showed intimate partner rejection predicted marital violence beliefs and dating violence attitudes.
\end{abstract}

KEYWORDS: intimate partner violence, acceptance-rejection, Cape Verdean students, Portugal

\section{Atitudes face à Violência entre Parceiros Íntimos e Aceitação-Rejeição pelo Par Amoroso em Estudantes Cabo-verdianos residentes em Portugal}

\begin{abstract}
RESUMO - O estudo procurou determinar a prevalência da violência na intimidade, caracterizar atitudes face à violência, analisar relações entre as percepções de aceitação pelo parceiro íntimo e a violência, averiguando relações entre a percepção de aceitação com as atitudes e crenças relativas à violência em alunos Cabo-verdianos residentes em Portugal. Cento e 16 participantes, entre os 15 e os 25 anos, oriundos de três escolas profissionais, quatro escolas secundárias e uma universidade, preencheram a Escala de Crenças sobre Violência Conjugal, Inventário de Violência Conjugal, Escalas de Violência no Namoro e Questionário de Aceitação-Rejeição pelo Par Amoroso. Encontraram-se correlações positivas significativas entre crenças, atitudes e rejeição pelo par amoroso. Regressões evidenciaram que a rejeição prediz crenças e atitudes relativas à violência.
\end{abstract}

PALAVRAS-CHAVE: violência entre parceiros íntimos, aceitação-rejeição, estudantes cabo-verdeanos, Portugal

Intimate partner violence is currently a significant social problem in Portugal (e.g., Neves \& Nogueira, 2010; Neves et al., 2016). Empirical evidence and statistical data suggest that Portuguese teenagers often experience violence in intimate relationships and that both secondary and university students are particularly vulnerable to victimization (Caridade, 2011; Caridade \& Machado, 2013; Machado, Caridade, \& Martins, 2010; Machado, Macieira, \& Carreiras, 2010;
Machado, Matos, \& Moreira, 2003; Paiva \& Figueiredo, 2004; Saavedra, 2011). Dating violence is a form of intimate partner violence that occurs between people aged 10 to 24 years old, current or former dating partners (Vagi et al., 2013). Dating violence is therefore a common and general term used to describe physical, psychological or sexual violence that happen within youth intimate relationships (Teten, Ball, Valle, Noonan, \& Rosenbluth, 2009).

*E-mail: asneves@ismai.pt

- Submetido: 31/10/2016; Revisado: 09/08/2017; Aceito: 03/10/2017. 
Machado et al. (2003) concluded that 15.5 per cent of the university students have been victimized by their romantic partners and that 21.7 per cent admitted to abusive behaviours in their intimate relationships, which reflects the magnitude of the phenomenon among Portuguese teenagers. Additionally, Paiva and Figueiredo (2004), encountered high levels of self-reported perpetration of psychological/ emotional violence (53.8 per cent), sexual violence (18.9 per cent) and minor physical violence ( 16.7 per cent) in a sample of Portuguese university students.

More recently, Machado, Caridade and Martins (2010), in a study conducted on a sample of 4,667 participants, aged between 13 and 29 years, concluded that 25.4 per cent had been exposed to at least one abusive act, in dating relationships, during the previous year (13.4 per cent reported having been victims of physical violence and 19.5 per cent of emotional violence). Moreover, 30.6 per cent reported being aggressive with their partners (18.1 per cent practised, at least once, physical abuse and 22.4 per cent emotional abuse act). Recently, Perista, Cardoso, Silva and Carrilho (2012) concluded that almost 7 per cent of girls and 4 per cent of boys were victims of dating violence and according to the European Union Agency for Fundamental Rights (FRA, 2014), 18 per cent of Portuguese women have experienced physical violence, 3 per cent have experienced sexual violence and 36 per cent have experienced a form of emotional or psychological abuse by a partner since the age of 15 .

In general, these studies tend to echo the results published in international studies (e.g., Fox, Corr, Gadd, \& Butler, 2014; O'Keefe, 1997; Straus, 2004). In fact, dating violence is usually characterized by mutual and reciprocal violence, where both boys and girls are described simultaneously as victims and aggressors, although the reasons and motivation for engaging in such behaviours are different and have different physical, emotional and social consequences (e.g., Neves, 2014). Besides, psychological violence is more frequently associated with higher levels of perpetration and sexual violence with lower levels of perpetration. Girls are more likely to experience injury, emotional abuse and sexual violence than boys (Swan \& Snow, 2002; Williams \& Frieze, 2005). Importantly, similar prevalence rates are not indicative of partner violent being the same for women and men. The meaning and motives are different for women and men (Neves, 2014; Swan \& Snow, 2006).

The above-mentioned results refer to the experiences of Portuguese-born students and studies with foreign or immigrant teenagers living in Portugal are almost nonexistent. Even though Portugal has a high rate of resident foreigners, a total number of 401,320 in 2013 (SEF, 2014), ${ }^{1}$ approximately 10.3 per cent of whom are children or adolescents (aged 0 to 14 years), little is known about

1 The Brazilian community remains the most prevalent with a total of 92,120 residents, followed by Cape Verde $(42,401)$ and Ukraine $(41,091)$. violence experienced in the midst of foreign communities in Portugal.

However, international studies results show the need for experiences of violence to be studied in foreign or immigrant populations (Crenshaw, 1991; Raj \& Silverman, 2002; Yick, 2000). Silverman, Decker and Raj (2007) pointed out that immigration might produce different effects, in terms of violence, across gender, age, sexual experience or ethnicity. Experiences of intimate partner violence are often exacerbated by immigrant-specific conditions such as language, isolation from and contact with family and community, change in economic status, legal status and the home country as a frame of reference (Menjívar \& Salcido, 2002).

If it is true that in some cases foreign young may benefit from their immigrant status in reducing vulnerability to dating violence (Silverman, Decker, \& Raj, 2007), in other cases immigration can increase the risk of exposure to this sort of violence (Ramos, Green, Booker, \& Nelson, 2011). In fact, ethnic differences are important in examining potential developmental precursors of dating violence (Windle \& Mrug, 2009). Recent studies indicate that young people from ethnic minority backgrounds (e.g. African-Americans and Hispanics) are at a higher risk of dating violence than their White counterparts (Ackard, Nuemark-Sztainer, \& Hannan, 2003; Foshee, Benefield, Ennett, Bauman, \& Suchindran, 2004). Being from a non-White background seems to increase considerably the likelihood of perpetration of violence among females, while possessing attitudes that are accepting of dating violence predicted perpetration by males (Foshee, Linder, MacDougall, \& Bangdiwala, 2001).

In addition to the social processes already mentioned, affecting both national and foreign citizens, although at different levels, studies have shown that there seems to be a relationship between intimate partner acceptance-rejection and the perpetration of dating violence acts (Volz, 2007; Volz \& Kerig, 2010). Thus, individuals who, in the past, experienced rejection by significant others, have a higher probability of being involved in abusive dating relationships (Downey, Feldman, \& Ayduk, 2005; Downey, Irwin, Ramsay, \& Ayduk, 2004; Leary, Twenge, \& Quinlivan, 2006).

In this research, we chose to study immigrant Cape Verdean teenagers and young adults living in Portugal for several reasons. Firstly, although this group is one of the most expressive in the country, in numerical terms, the lack of research-based knowledge on this community is evident. This is even more noticeable when we consider interpersonal violence. In Portugal, in 2013, educational custodial measures were applied to 397 foreign young people (216 from Africa, 90 of whom were from Cape Verde), representing approximately 10 per cent of the total number of measures applied in Portugal (2969) (Directorate-General for Reintegration and Prison Services - DGRSP, 2013). 
Findings from previous studies confirm that both female and male immigrant Cape Verdean young people are being directly and indirectly exposed to violence (e.g., Lima, 2007). Despite this, little or nothing is known about intimate partner violence perpetrated among teenagers, especially about dating violence and its consequences.

Intimate partner violence is a well-recognized problem in Cape Verde (González, 2013). Based on the II Demographic and Reproductive Health Survey, conducted by the National Institute of Statistics (National Institute of Statistics [INE] et al., 2005), 22 per cent of women (one in five), aged 15 to 49, have suffered from emotional, physical or sexual violence perpetrated by a partner or a former partner. Most of victims were married or lived with the aggressor. Although, dating violence numbers are not known and most of the perpetrated violence had occurred since the age of 15 .

The previously mentioned evidence is corroborated by statistical data on violence against immigrant women in Portugal. According to the Support Unit for Migrant Victims and Victims and of Racial and Ethnical Discrimination (UAVIDRE, 2013), part of The Portuguese Association for Victim Support (APAV), from a total of 371 cases of violence against foreign people registered, 24 were against Cape Verdean citizens, the second most victimized group, after the Brazilians (121). Domestic violence was the most reported crime ( 75 per cent). Data about dating violence among young people are not available.

In informal contacts, Cape Verdean immigrant associations have finally identified dating violence as a serious concern, signalling the need for studies to be conducted on this topic.

Considering the arguments above, this study sought to answer to the following research questions: is there a relation between beliefs about marital violence, dating violence attitudes and intimate partner rejection? If so, how is it characterised?

The objectives were: (1) to determine the prevalence of intimate partner violence among Cape Verdean student's living in Portugal; (2) to assess beliefs and attitudes toward intimate partner violence; (3) to analyse the relations between perceptions of intimate partner acceptance-rejection and practices of intimate partner violence; (4) To analyse relations between intimate partner acceptance-rejection and beliefs and attitudes toward intimate partner violence.

\section{METHOD}

\section{Participants and Procedures}

A convenience sample was constituted by 116 Cape Verdean residing in Portugal, aged 15 to 25 years old ( $M=$ $19.4 ; S D=2.23$ ). Data suggest that up to the age of 15 , one quarter of Cape Verdean girls and 41 per cent of boys are already sexually active (INE et al., 2005). In addition, adolescent dating violence is believed to emerge between the ages of 15 and 16 (Bethke \& DeJoy, 1993). The inclusion criteria were: (1) to have Cape Verdean nationality; (2) have been living in Portugal for a minimum period of one year; (3) be aged between 15 and 25 years. The sample was constituted by 53.4 per cent of female and 46.6 per cent of male participants. Seventy-five per cent of the sample reported being in a current intimate relationship, without cohabitation. 52.7 per cent of participants had been residing in Portugal for a period of between 1 to 4 years and 25.7 per cent for more than 4 years and 21.6 per cent for less than one year.

Data was collected from three professional schools, four secondary schools and 1 university in Oporto, after the approval of the school boards. Schools were chosen based on the high prevalence of Cape Verdean teenagers on the school enrolment. Once informed consent to collect data had been obtained, the participants completed four questionnaires individually in a class context. For those under the age of 18 , informed consent was requested from their legal guardians.
Since the phenomenon is undocumented in Portugal, we decided to use measures and methods that allow its characterization, so we chose quantitative instead of qualitative methods. Qualitative studies will be conducted in a second phase.

\section{Measures}

Scale of beliefs about marital violence. The Scale of Beliefs about Marital Violence (SBMV; Matos, Machado, \& Gonçalves, 2000a) analyses beliefs about both physical and psychological violence in intimate relationships, that is, it evaluates how violence is seen as legitimate and tolerated in intimate partner relationships. It includes 25 items, which are answered using a Likert scale (ranging from 1 - completely disagree to 5 - totally agree). With a factor analysis, four factors have been identified which explain 48.1 per cent of the variance (Machado, Matos, \& Gonçalves, 2006).

The first factor, supporting violence due to a woman's misconduct, includes statements that display beliefs that normalize and banalize minor violence (such as slapping and insulting) and it explains 30.5 per cent of the common variance; the second factor, supporting violence due to family privacy explains 6.9 per cent of the common variance; the third factor supports violence as a result of external causes (explaining 5.6 per cent of the common variance); the fourth factor is the minimization of small acts of violence (explaining 5.1 per cent of the common variance). 
Scores are obtained from the sum of the items related to each factor. The total score assesses the degree of tolerance and acceptance of marital violence. Each factor score allows for a better understanding of each individual's tolerance of marital violence (Machado, Matos, \& Gonçalves, 2006). Reliability analysis, performed by the scale's authors using Cronbach's alpha, showed a value of .90, whereas in our study, the alpha reached .93 .

Marital Violence Inventory. It's an inventory of behaviours and an attitude scale that aims to identify victimization and/or perpetration of violent behaviours in intimate relationships. The MVI determines prevalence and frequency of physical and emotional violence both perpetrated and received by intimate partners (MVI; Matos, Machado, \& Gonçalves, 2000b)

This inventory has two parts in which 21 types of violent acts (inflicted and/or received) are presented. ${ }^{2}$ The first part of the inventory refers to relationships in the past year; the second part to any previous intimate relationship. Each part is then divided into two other sections: one for behaviours inflicted by the respondent towards his/her partner and another for behaviours inflicted by the respondent's partner towards him/herself. Original reliability analysis, assessed using Cronbach's alpha, showed values of .93 (Machado, Matos, \& Gonçalves, 2006), whereas for our sample, alpha values reached .90 .

Dating violence scales. Dating Violence Scales (DVS; Byers, Price, \& The Dating Violence Research Team, 1999, adapted by Saavedra, 2011) are a self-report questionnaire comprising 76 items organized in three attitudes toward male dating violence sub-scales and three attitudes towards female dating violence sub-scales. Sub-scales assess respondents' attitudes towards psychological, physical and sexual violence in these relationships.

Answers are given using a Likert type scale (ranging from 1 - totally disagrees to 5 - totally agrees) and respondents should be aged between 12 to 19 years. For each scale, the highest scores show greater acceptance of different types of violence, in other words, a view of violence or the perpetration of violence as legitimate (Price, Byers, Sears, Whelan \& Saint-Pierre, 2000). In the original study, with 580 students, reliability values for each scale were considered adequate, with results ranging from .75 to .87 (Cronbach's alpha).
In Portugal, Dating Violence Scales were adapted by Saavedra (2011) using a sample of 411 students, with ages ranging from 13 to 19 years $(\mathrm{M}=14.7$; $\mathrm{DP}=0.92)$, where 214 (52.1per cent) were female and 197 (47.9per cent) were male. Cronbach's alpha for the total scale was .94, thus showing high reliability. In our study, reliability indicators reached .75 (Cronbach's alpha) with subscale values ranging from .77 to .84 .

Intimate Partner Acceptance-Rejection/Control Questionnaire. Based on Rohner's Interpersonal Acceptance-Rejection Theory, the Intimate Partner Acceptance-Rejection/Control Questionnaire (Rohner, $2005)$ is a self-report measure that evaluates each individual's perception of being more or less accepted or rejected and controlled by his or her intimate partner.

This instrument has two distinct parts, the first being a group of questions where the objective is to assess each individual's past and present relationship status (whether respondents are now or have been at any time during the past year in an intimate relationship; whether the relationship is still ongoing; the duration of the relationship; nature of the relationship; and the extent to which the respondents' sense of emotional security, comfort and well-being is/was affected by their feelings about their relationship) (Rohner $\&$ Khaleque, 2005).

The second part features 73 items organized in a Likert scale format that ranges from 4 (almost always true) to 1 (almost never true). These items are grouped together to form 5 sub-scales: Warmth/Acceptance, Hostility/Aggression, Indifference/Neglect, Undifferentiated Rejection (this sub-scale refers to individuals' belief that their partners do not really love, want, appreciate, or care about them, without necessarily experiencing any clear behavioural indicators that their partners are behaviourally neglecting, unaffectionate, or aggressive toward them) and Control (Rohner \& Khaleque, 2005). The Portuguese version of the Questionnaire was adapted by Machado and Machado (2009).

This measure presents a global score of intimate partner rejection. Reliability analysis from the original study showed values of Cronbach's Alpha of .80 for the global rejection score of the questionnaire, whereas in the present study, reliability analysis showed a Cronbach's alpha of .88 for the global rejection score.

\section{RESULTS}

The results from our descriptive analysis are portrayed in three different tables for a more clear view of the data,

2 For analysis purposes individuals are considered to be aggressors if they admit to at least one behavior considered as physical or emotional abuse in either the present or the past. Individuals considered as non-aggressors are those who, having answered the entire questionnaire, deny having perpetrated any kind of abusive behavior. namely table 1,2 and 3 . The results on table 1 pertain to abusive behaviours, and show that participants, both male and female, practise and suffer and have suffered from abusive behaviours in both present and past relationships. In table 2 we have the descriptive results relative to beliefs about marital violence, which indicate that the mean values were below, yet close, to the midpoints of the scales. When 
Table 1

Descriptive statistics for abusive behaviours

\begin{tabular}{|c|c|c|c|c|c|c|c|c|c|c|c|c|c|}
\hline \multirow[b]{2}{*}{ Relationship } & \multirow[b]{2}{*}{ Abusive behaviour } & \multicolumn{6}{|c|}{ Suffered } & \multicolumn{6}{|c|}{ Practiced } \\
\hline & & Min. & Max. & $\mathbf{M}$ & SD & $\mathbf{n}$ & $\mathbf{t}$ & Min. & Max. & $\mathbf{M}$ & SD & $\mathbf{n}$ & $\mathbf{t}$ \\
\hline \multirow{6}{*}{ Current } & Physical & & & & & & & & & & & & \\
\hline & Male & 13.00 & 28.64 & 15.15 & 3.92 & 62 & -0.04 & 13.00 & 31.00 & 14.34 & 3.69 & 62 & -0.62 \\
\hline & Female & 13.00 & 31.00 & 15.18 & 3.96 & 54 & & 13.00 & 26.00 & 14.75 & 3.56 & 54 & \\
\hline & Emotional & & & & & & & & & & & & \\
\hline & Male & 7.00 & 18.00 & 8.86 & 2.95 & 62 & 0.92 & 7.00 & 15.15 & 8.13 & 2.03 & 62 & -0.13 \\
\hline & Female & 7.00 & 19.00 & 8.38 & 2.63 & 54 & & 7.00 & 16.00 & 7.95 & 1.94 & 54 & \\
\hline \multirow{6}{*}{ Past } & Physical & & & & & & & & & & & & \\
\hline & Male & 13.00 & 29.00 & 15.04 & 3.99 & 62 & 0.19 & 13.00 & 34.07 & 14.64 & 4.18 & 62 & 0.41 \\
\hline & Female & 13.00 & 27.00 & 14.90 & 3.67 & 54 & & 13.00 & 28.00 & 14.35 & 3.18 & 54 & \\
\hline & Emotional & & & & & & & & & & & & \\
\hline & Male & 7.00 & 19.00 & 8.72 & 3.33 & 62 & 0.56 & 7.00 & 20.00 & 8.23 & 2.76 & 62 & 0.49 \\
\hline & Female & 7.00 & 19.00 & 8.38 & 3.19 & 54 & & 7.00 & 16.00 & 8.01 & 2.03 & 54 & \\
\hline
\end{tabular}

Table 2

Descriptive statistics for beliefs about marital violence

\begin{tabular}{|c|c|c|c|c|c|c|}
\hline Measures & Min & Max & $\mathbf{M}$ & SD & $\mathbf{n}$ & $\mathbf{t}$ \\
\hline \multicolumn{7}{|c|}{ SV women's misconduct } \\
\hline Male & 10 & 41 & 26.00 & 8.03 & 62 & .988 \\
\hline Female & 10 & 42 & 24.50 & 8.33 & 54 & \\
\hline \multicolumn{7}{|c|}{ SV family privacy } \\
\hline Male & 6 & 26 & 17.12 & 5.21 & 62 & .688 \\
\hline Female & 6 & 28 & 16.42 & 5.74 & 54 & \\
\hline \multicolumn{7}{|c|}{ SV external attributes } \\
\hline Male & 9 & 35 & 21.48 & 6.62 & 62 & -.125 \\
\hline Female & 9 & 37 & 21.64 & 7.20 & 54 & \\
\hline \multicolumn{7}{|l|}{ MSV } \\
\hline Male & 16 & 61 & 37.04 & 12.75 & 62 & .102 \\
\hline Female & 16 & 67 & 36.79 & 13.38 & 54 & \\
\hline \multicolumn{7}{|c|}{ SBMV total score } \\
\hline Male & 42 & 155 & 101.64 & 28.69 & 62 & .402 \\
\hline Female & 41 & 173 & 99.35 & 32.76 & 54 & \\
\hline
\end{tabular}

Note. SV, Supporting violence; MSV, minimization of small violence; SBMV, Scale of beliefs about marital violence.

we analyse on table 3 , where the descriptive data relative to attitudes towards dating violence and intimate partner acceptance is shown, we can see that the mean values for the attitudes towards dating violence follow the same trend as the previous variable and are also bellow, yet close, to the midpoint of the scale. As far as intimate partner acceptance was concerned, the descriptive data depicted also in table 3 , pointed to participants considering themselves, generally, as being accepted by their partners.

In terms of dating violence attitudes, table 3 shows us all the results obtained from the comparison analysis between male and female subjects, in terms of attitudes towards male dating violence, attitudes towards female dating violence and intimate partner acceptance. These results show that only attitudes towards male psychological dating violence were significantly higher in male students.

Analyses of correlations were run separately for male and female students. For the purpose of presenting results, correlations between dimensions in the same instruments will not be presented in the results section.

For male students, positive correlations (table 4) were found between support of violence justified by women's misconduct for every variable studied, with the exception of physical and sexual attitudes towards female dating violence $\left(\mathrm{AFDV}^{3}\right)$. Similar results were found for minimization of small violent acts where correlations were found for all

3 Attitudes towards female dating violence. 
Table 3

Descriptive statistics for attitudes towards dating violence and intimate partner acceptance

\begin{tabular}{|c|c|c|c|c|c|c|}
\hline Measures & Min & Max. & $\mathbf{M}$ & SD & $\mathbf{n}$ & $\mathbf{t}$ \\
\hline \multicolumn{7}{|c|}{ AMDV - Psychological } \\
\hline Male & 23.00 & 67.00 & 41.29 & 9.56 & 62 & $2.54 *$ \\
\hline Female & 23.00 & 57.00 & 37.20 & 7.49 & 54 & \\
\hline \multicolumn{7}{|c|}{ AMDV - Physical } \\
\hline Male & 22.00 & 48.00 & 33.86 & 6.21 & 62 & 0.92 \\
\hline Female & 22.00 & 48.00 & 32.80 & 6.10 & 54 & \\
\hline \multicolumn{7}{|c|}{ AMDV - Sexual } \\
\hline Male & 18.00 & 50.00 & 29.07 & 8.58 & 62 & 1.65 \\
\hline Female & 14.00 & 44.00 & 26.63 & 7.04 & 54 & \\
\hline \multicolumn{7}{|c|}{ AFDV - Psychological } \\
\hline Male & 17.00 & 57.00 & 31.05 & 8.83 & 62 & -1.39 \\
\hline Female & 15.00 & 51.00 & 33.20 & 7.72 & 54 & \\
\hline \multicolumn{7}{|c|}{ AFDV - Physical } \\
\hline Male & 22.00 & 48.00 & 34.23 & 5.70 & 62 & -0.15 \\
\hline Female & 24.00 & 45.00 & 34.38 & 5.19 & 54 & \\
\hline \multicolumn{7}{|c|}{ AFDV - Sexual } \\
\hline Male & 24.00 & 51.00 & 33.74 & 5.84 & 62 & 0.67 \\
\hline Female & 23.00 & 48.00 & 33.03 & 5.46 & 54 & \\
\hline \multicolumn{7}{|c|}{ Intimate partner acceptance } \\
\hline Male & 67.00 & 174.00 & 111.18 & 28.64 & 62 & -0.40 \\
\hline Female & 64.00 & 190.00 & 113.41 & 31.72 & 54 & \\
\hline
\end{tabular}

Note. AMDV: Attitudes towards male dating violence; AFDV: Attitudes towards female dating violence.

variables except physical violence (AFDV). On the other hand, little correlation was found between supports for violence due to the protection of family privacy, which was only positively correlated with psychological attitudes towards male dating violence $\left(\mathrm{AMDV}^{4}\right)$. The same result was found for support of violence due to external attributes. The total score for beliefs about marital violence was positively correlated to all scales for AMDV and for the psychological factor of AFDV, as well as perceived rejection by an intimate partner.

Focusing on the attitudes towards dating violence, male attitudes were all positively correlated with rejection by an intimate partner, while only psychological and female sexual attitudes were correlated with the aforementioned dimension.

Finally, perceived intimate partner rejection was positively correlated with beliefs that support violence due to a woman's misconduct, the minimization of small acts of violence and the total scale score. It was also correlated with all AMDV and with psychological and sexual AFDV.

Looking into the correlations found for female students (table 4), positive and significant, correlations were found between beliefs supporting violence caused by a woman's misconduct and sexual AMDV, psychological and physical

4 Attitudes towards male dating violence.
AFDV and perceived rejection. The belief supporting violence in order to protect the family was only correlated with psychological AFDV. Beliefs supporting violence caused by external attributes, was only correlated to intimate partner rejection. Minimization of small violent acts was correlated with sexual AMDV, physical AFDV, psychological AFDV and perceived rejection. The total scale of violent beliefs was correlated with psychological and physical AFDV, as well as with intimate partner rejection.

All the AMDV and AFDV scales were also correlated with perceived intimate partner rejection.

\section{Regressions}

Linear regressions were run with intimate partner rejection as a predictor and violent beliefs as dependent variables. Durbin-Watson values were within the acceptable range for all models.

Intimate partner rejection was shown to be a predictor (table 5) among both male and female adolescents of beliefs of legitimation of violence, of the minimization of small violent acts, as well as the legitimation of violence due to a woman's misconduct. For girls only, but not for boys, intimate partner rejection was a predictor of legitimation of violence caused by external attributes. 
Correlations between violence beliefs, dating violence and intimate partner acceptance

\begin{tabular}{|c|c|c|c|c|c|c|c|c|c|c|c|c|}
\hline & 1 & 2 & 3 & 4 & 5 & 6 & 7 & 8 & 9 & 10 & 11 & 12 \\
\hline $\begin{array}{l}\text { 1. SV women's } \\
\text { misconduct }\end{array}$ & --- & $.77 * *$ & $.72 * *$ & $.85^{* *}$ & $.96^{* *}$ & $.55^{* *}$ & $.48^{* *}$ & $.43 * *$ & $.35^{* *}$ & -.04 & .21 & $.34 * *$ \\
\hline $2 \mathrm{SV}$ family privacy & $.85^{* *}$ & --- & $.74 * *$ & $.60^{* *}$ & $.83 * *$ & $.36^{* *}$ & .24 & .25 & .19 & .06 & -.00 & .17 \\
\hline 3. SV external attributes & $.85^{* *}$ & $.84 * *$ & --- & $.47 * *$ & $.77 * *$ & $.26^{*}$ & .19 & .11 & .10 & -.05 & -.05 & .12 \\
\hline 4. MSV & $.91 * *$ & $.83 * *$ & $.82 * *$ & --- & $.90 * *$ & $.62 * *$ & $.61 * *$ & $.55^{* *}$ & $.46^{* *}$ & .04 & $.35^{* *}$ & $.52 * *$ \\
\hline 5. SBMV total score & $.96^{* *}$ & $.91 * *$ & $.92 * *$ & $.97 * *$ & --- & $.56^{* *}$ & $.49 * *$ & $.43 * *$ & $.36 * *$ & .01 & .21 & $.39 * *$ \\
\hline $\begin{array}{l}\text { 6. AMDV - } \\
\text { Psychological }\end{array}$ & .23 & .22 & .09 & .25 & .22 & --- & $.67 * *$ & $.75^{* *}$ & $.44 * *$ & .11 & $.31^{*}$ & $.28 *$ \\
\hline 7. AMDV - Physical & .14 & .12 & .10 & .21 & .16 & $.38 * *$ & --- & $.58^{* *}$ & $.47 * *$ & .03 & $.40 * *$ & $.33 * *$ \\
\hline 8. AMDV - Sexual & $.28^{*}$ & .24 & .08 & $.31 *$ & .27 & $.48 * *$ & $.40 * *$ & --- & $.37 * *$ & .02 & $.52 * *$ & $.33 * *$ \\
\hline 9. AFDV - Psychological & $.35^{*}$ & $.28^{*}$ & .22 & $.39 * *$ & $.34 *$ & $.34 *$ & $.28^{*}$ & $.42 * *$ & --- & .19 & $.29^{*}$ & $.36 * *$ \\
\hline 10. AFDV - Physical & $.35^{*}$ & .22 & .22 & $.35 * *$ & $.32 *$ & $.28 *$ & .02 & $.43^{* *}$ & $.41 * *$ & --- & .05 & .10 \\
\hline 11. AFDV - Sexual & .13 & .18 & .02 & .18 & .14 & .21 & .23 & $.62 * *$ & $.40 * *$ & $.29^{*}$ & --- & $.29 *$ \\
\hline 12. IPA & $.38 * *$ & .24 & $.33 *$ & $.42 * *$ & $.38 * *$ & $.28 *$ & $.28 *$ & $.44 * *$ & $.28 *$ & $.40 * *$ & $.30^{*}$ & --- \\
\hline
\end{tabular}

Note Coefficients above the diagonals pertain to males; coefficients below the diagonals pertain to females. SV, Supporting violence; MSV, minimization of small violence; SBMV, Scale of beliefs about marital violence; AMDV: Attitudes towards male dating violence; AFDV: Attitudes towards female dating violence.

Table 5

Linear Regression Analysis for the Influence of Partner Acceptance on Students' Violence Beliefs

\begin{tabular}{|c|c|c|c|c|c|c|c|c|}
\hline \multirow[b]{2}{*}{ Dependent variables } & \multicolumn{4}{|c|}{ Male Students } & \multicolumn{4}{|c|}{ Female students } \\
\hline & & $\rightarrow$ & $R^{2}$ & $R^{2}$ & & $\rightarrow$ & $R^{2}$ & $R^{2}$ \\
\hline & & & .27 & .26 & & & .18 & .16 \\
\hline Constant & 11.10 & & & & 16.76 & & & \\
\hline MSV & & $.52 * *$ & & & & $.42 * *$ & & \\
\hline & & & .11 & .10 & & & .15 & .13 \\
\hline Constant & 15.54 & & & & 13.09 & & & \\
\hline $\begin{array}{l}\text { SV women's } \\
\text { misconduct }\end{array}$ & & $.34 * *$ & & & & $.38^{* *}$ & & \\
\hline & & & .01 & -.00 & & & .11 & .09 \\
\hline Constant & 18.44 & & & & 13.11 & & & \\
\hline SV external attributes & & .12 & & & & $.33^{*}$ & & \\
\hline & & & .03 & .01 & & & .06 & .04 \\
\hline Constant & 13.73 & & & & 11.58 & & & \\
\hline SV family privacy & & .17 & & & & .24 & & \\
\hline
\end{tabular}

\section{DISCUSSION AND CONCLUSIONS}

The purpose of this study was to characterize intimate partner violence beliefs, attitudes and practices among Cape Verdean male and female adolescents and young adulten resident in Portugal, analysing the relationship between beliefs, attitudes and practices of intimate partner violence and perceptions of intimate partner acceptance-rejection.

Similar to other studies about intimate partner violence within immigrant communities, our research suggests that both female and male Cape Verdean teenagers and young adults practise and suffer from violence in their dating relationships. Identifying the problem, based on information provided by those directly involved and affected, may be a first step to understanding why and how intimate partner violence persists and is maintained in foreign countries. In addition, as Wekerle and Wolfe (1999) remind us: "this finding has implications for prevention because a coercive 
and violent dynamic may form during adolescence, in contrast to the perpetrator-only and victim-only roles of adulthood" (pp. 437).

According to the Cape Verde's First National Plan to Combat Gender-Based Violence (Cape Verdean Institute for Gender Equity and Equity - ICIEG, 2006), in the last decade, the phenomenon has increased considerably in size, with women being doubly victimized. Although women are, in the initial stages of violence, mostly victims, when they react and respond, in most of cases in self-defence, to the violent acts perpetrated by their male partners, they also become aggressors, which tends to create a double condition of social vulnerability (ICIEG, 2006). One of the hypotheses of our study is that female Cape Verdeans in Portugal are probably reproducing this reactive tendency, widely reported in literature and also recognized in Portugal, usually referred to as mutual violence. In fact, girls are frequently described as circumstantial aggressors, using violence, in dating relationships, particularly as a self-defence strategy (Kelley, Edwards, Dardis, \& Gidycz, 2015). Thus, they tend to use violence as an approach to end chronic abuse (ICIEG, 2006), which can put them in very dangerous situations. As shown in previous studies, in the Cape Verdean context, when women became aggressors the severity of violence is usually higher.

Although the differences between genders are not significant in terms of dating violence practices, our results indicate, with regard to attitudes, that attitudes towards male psychological dating violence are significantly higher in male students. This means that boys tend to tolerate, more than girls, psychological dating violence perpetrated by them. From both structural and feminist perspectives, male acceptance of physical, psychological and sexual violence within intimate relationships has been associated with a need for assurance of male dominance and power. The research suggest that young menen genders are not perpetration may be associated to internalized misogynistic social norms, revelling adversarial sexual beliefs, sex-role stereotyping, adherence to traditional gender roles, and dissatisfaction with power in the relationship (e.g., Torres et al., 2012). The fact that it is social and culturally expected that men are more powerful than their female partners, as the intimate relationships are naturally unequal, therefore, legitimates the use of all types of violence, including psychological violence (e.g., Kaukinen, 2014). An assessment of attitudes among young people is important because it provide clues for preventing violence in adulthood, since it is known that dating violence is a predictor of spousal abuse. As well, a critical understanding of gender differences and similarities in intimate partner violence is fundamental in order to increase prevention (Dardis, Dixon, Edwards, \& Turchik, 2014).

The same argument could be presented to explain why male students support violence justified by a woman's misconduct for every variable studied, except for physical and sexual attitudes towards female dating violence, as well as why they minimize small violent acts. Women and men are expected to behave according to certain pre-fixed gender roles and attributes (Amâncio, 1994). When women behave completely differently to what is expected from them, violence perpetrated by men tends to be considered a legitimate resource to restore normality. It is essential to underline that historically violence has been seen as an effective way of dealing with female 'misconduct', namely by law. Misconduct refers to all behaviours that are perceived as inappropriate for women, according to cultural and moral conservative standards.

This representation seems to be so socially rooted that young female Cape Verdeans also justify violence based on their own misconduct. More worrying still is their alleged tolerance to sexual violence perpetrated by men using their own misbehaviour as an excuse. The belief that women deserve to be punished sexually as a consequence of their misconduct, is a serious risk factor for sexual violence against women. As some studies pointed out (e.g., LeMaire, Oswald, \& Russell, 2016) rape myth acceptance is associated with a tendency to deny and justify male sexual aggression towards women, both by men and women, which deprotects the victims and protects the aggressors. Our results therefore reinforce the imperative need to empower girls as a strategy to achieve gender equality.

Despite the fact that, in this study, female and male students generally perceived their partners to be accepting, male beliefs supporting violence against women seem to be associated with the perception of being rejected by partners, either intimate partner rejection, in our study, or even a predictor of marital violence beliefs and dating violence attitudes. This evidence confirms what previous research has shown, that real or perceived rejection plays an important role in violence between romantic partners (Leary, Twenge, \& Quinlivan, 2006). Once more, cultural norms may prescribe aggressive behaviour in response to real or implied rejection. Curiously this evidence was also found in female students, supporting the idea that intimate partner rejection could have serious consequences, at several levels, in both genders (Rohner, Khaleque, \& Cournoyer, 2005). Thus, findings from this research support the importance of analysing intimate partner acceptance/rejection in the study of intimate partner violence.

In conclusion, it is important to note that this study is pioneering due to its contribution to uncovering a problem that was almost obscured in Portuguese society. Problems of school absenteeism, poor social integration, social discrimination, delinquent behaviour, and drug abuse among Cape Verdean young people are already documented, but empirical evidences of dating violence perpetrated inside this foreign community was missing. It seems clear now that dating violence among immigrant Cape Verdean young people is characterized by reciprocity and mutuality, following both international and national patterns of dating 
violence described in the literature. Violent practices and attitudes of toleration and acceptance towards violence seem to be related and are culturally bound. Female misconduct seems to play an important role in justifying acts of abuse within intimate relationships, for both girls and boys, suggesting that both genders share traditional social representations about what it means to be a good girl/woman and, more than that, how they should be punished when they behave in the wrong way. Lastly, this study shows that intimate partner rejection can be a predictor of beliefs related to the legitimation of violence for both genders, confirming the association between the perception of rejection and the tendency to be involved in risky behaviours within intimate relationships.

\section{Limitations and Future Research}

This study allows us to conclude that dating violence seems to be a significant problem among Cape Verdean teenagers and young adults living in Portugal, showing that patterns of reciprocal and mutual physical and psychological aggression tend to characterize their intimate relations, as most of international studies in this field have demonstrated. Although evidences suggest there is an absence of differences between sexes, concerning perpetration and victimization, beliefs and attitudes toward dating violence indicate different gender expectations according sex. This is particularly relevant considering that female misconduct appears as a legitimation factor in violence perpetration, both for boys or for girls, as tolerance of sexual violence is linked to the idea of punishing this conduct. Also relevant in this study is the fact that intimate partner rejection constitutes a predictor of marital violence beliefs and dating violence attitudes. Actually, male beliefs about violence against women seem to be associated with the perception of being rejected by partners and these new results suggest there are new possibilities for studying the relation between intimate partner rejection and intimate partner violence.

Although innovative, this research has some limitations. One of them is the size of sample. Due to time and human resource constraints, the study did not reach statistical representativeness. Thus, the size of the sample limits the generalization of the results.

The second limitation concerns the impossibility of combining quantitative and qualitative methods. Many of the results would benefit from a descriptive and comprehensive approach that a quantitative study cannot provide. Thus, future research should focus on the qualitative analysis of the factors and the motives that favour dating violence. In-depth interviews with victims and perpetrators must be conducted in order to capture their understanding of the phenomenon and characterize contexts of violence and their dynamics.

Questions about the influence of migration process on dating violence must be explored, as well as the resources available to Cape Verdean young people to face the consequences of victimization in a foreign country.

The relation between intimate partner rejection and dating violence must be detailed in forthcoming studies, to better understand why rejection seems to predict aggressive behaviours.

\section{REFERENCES}

Ackard, D., Nuemark-Sztainer, D., \& Hannan, P. (2003). Dating violence among a nationally representative sample of adolescent girls and boys: Associations with behavioural and mental health. Journal of Gender Specific Medicine, 6(3), $39-48$.

Amâncio, L. (1994). Masculino e feminino. A construção social da diferença. Oporto: Afrontamento.

Andrade, M. O. (1996). Ethnic identity dimensions and psychological functioning of Cape Verdean-Americans: An exploratory study. Dissertation Abstracts International, 57(11).

Bethke, T. M., \& DeJoy, D. M. (1993). An experimental study of factors influencing the acceptability of dating violence. Journal of Interpersonal Violence, 8, 36-51.

Cape Verdean Institute for Gender Equity and Equity. (2006), Plano nacional de combate à Violência baseada no Género. Praia: ICIEG.

Caridade, S. (2011). Vivências violentas. Uma abordagem cientifica. Coimbra: Almedina.

Caridade, S., \& Machado, C. (2013). Violência nas relações juvenis de intimidade: Uma revisão da teoria, da investigação e da prática. Psicologia, 27(1), 91-113.

Crenshaw, K. (1991). Mapping the margins: Intersectionality, identity, politics and violence against women of colour. Stanford Law Review, 43, 1241-1299.

Dardis, C., Dixon, K., Edwards, K., \& Turchik, J. (2014). An examination of the factors related to dating violence perpetration among young men and women and associated theoretical explanations: A review of the literature. Trauma, Violence, \& Abuse, 16, 136-152. doi: 10.1177/1524838013517559

Directorate-General for Reintegration and Prison Services. (2013). Relatório Estatístico Anual - Reinserção Social. Lisbon: DGRSP.

Downey, G., Feldman, S., \& Ayduk, O. (2005). Rejection sensitivity and male violence in romantic relationships. Personal Relationships, 7(1), 45-61. doi: 10.1111/j.1475-6811.2000. tb00003.x

Downey, G., Irwin, L., Ramsay, M., \& Ayduk, O. (2004). Rejection sensitivity and girls' aggression. In M. M. Moretti, C. L. Odgers \& M. A. Jackson (Eds.), Girls and aggression: Contributing factors and intervention principles (pp. 7-25). New York, NY: Kluwer Academic/Plenum Publishers.

European Union Agency for Fundamental Rights. (2014). Violence against women: An EU-wide survey, Austria: FRA.

Foshee, V. A., Benefield, T. S., Ennett, S. T., Bauman, K. E., \& Suchindran, C. (2004). Longitudinal predictors of serious physical and sexual dating violence victimization during adolescence. Preventive Medicine, 39, 1007-1016.

Foshee, V. A., Linder, F., MacDougall, J. E., \& Bangdiwala, S. (2001). Gender differences in the longitudinal predictors of adolescent dating violence. Preventive Medicine, 32, 128-141. 
Fox, C., Corr, M., Gadd, D., \& Butler, I. (2014). Young teenagers' experiences of domestic abuse. Journal of Youth Studies, 17(4), 510-526. doi: 10.1080/13676261.2013.780125

Gonçalves, L. (2013). Caboverdianas en burela (1978/2008): Migración, relacións de xénero e intervención social (Tese de Doutorado). Universidad de Santiago de Compostela, Santiago de Compostela, Espanha.

Kaukinen, C. (2014). Dating violence among college students. Trauma, Violence, \& Abuse, 15(4), 283-296. doi: $10.1177 / 1524838014521321$

Kelley, E. L., Edwards, K. M., Dardis, C. M., \& Gidycz, C. A. (2015). Motives for physical dating violence among college students: A gendered analysis. Psychology of Violence, 5(1), 56-65. doi: 10.1037/a0036171

Leary, M., Twenge, J., \& Quinlivan, E. (2006). Interpersonal rejection as a determinant of anger and aggression. Personality and Social Psychology Review, 10(2), 111-132. doi: 10.1207/ s15327957pspr1002 2

LeMaire, K., Oswald, D., \& Russell, B. (2016). Labeling sexual victimization experiences: the role of sexism, rape myth acceptance, and tolerance for sexual harassment. Violence and Victims, 31(2), 332-346. doi: 10.1891/0886-6708.VVD-13-00148

Lima, A. (2007). Searching for rainbows: Race, ethnicity, gender and the socialization of Cape Verdean immigrant youth within family, school and community contexts. Dissertation Abstracts International, 68(6).

Machado, C., Caridade, S., \& Martins, C. (2010). Violence in juvenile dating relationships self-reported prevalence and attitudes in a Portuguese sample. Journal of Family Violence, 25, 43-52. doi: 10.1007/s10896-009-9268-x

Machado, C., Matos, M., \& Moreira, A. I. (2003). Violência nas relações amorosas: Comportamentos e atitudes na população universitária. Psychologica, 33, 69-83.

Machado, T., Macieira, I., \& Carreiras, M. (2010). Violência nas relações de namoro: Influência de crenças e área de formação. Revista Psicologia, Educação e Cultura, XIV(2), 355-399.

Matos, M., Machado, C., \& Gonçalves, M. M. (2000a). E.C.V.C. - Escala de Crenças sobre Violência Conjugal. Braga: Universidade do Minho, Instituto de Educação e Psicologia.

Matos, M., Machado, C., \& Gonçalves, M. M. (2000b). I.V.C. Inventário de violência conjugal. Braga: Universidade do Minho, Instituto de Educação e Psicologia.

Machado, C., Matos, M., \& Gonçalves, M. (2006). Manual da escala de crenças de violência conjugal e do inventário de violência conjugal. Braga: Universidade do Minho.

Menjívar, C., \& Salcido, O. (2002). Immigrant women and domestic violence: Common experiences in different countries. Gender \& Society, 16(6), 898-920. doi: 10.1177/089124302237894

National Institute of Statistics (INE) [Cabo Verde], Ministério da Saúde \& Macro International (2008). Segundo inquérito demográfico e de saúde reprodutiva, Cabo Verde, IDSR-II, 2005. Calverton, Maryland, USA: INE.

Neves, S. (2014). De vítimas a agressoras: A (aparente) dupla posição das raparigas na violência no namoro heterossexual. In V. Duarte \& M. I. Cunha (Coord.), Violências e Delinquências juvenis femininas: Género e (in)visibilidades sociais (pp. 63-76). Famalicão: Editora Húmus.

Neves, S., Cameira, M., Machado, M., Duarte, V., \& Machado, F. (2016). Beliefs on marital violence and self-reported dating violence: A comparative study of Cape Verdean and Portuguese adolescents. Journal of Child and Adolescent Trauma, 1-8. doi: 10.1007/s40653-016-0099-7

Neves, S., \& Nogueira, C. (2010). Deconstructing gendered discourses of love, power and violence in intimate relationships. In D. C. Jack \& A. Ali (Eds), Silencing the self across cultures depression and gender in the social world (pp. 241-261). Oxford: Oxford University Press.
O'Keefe, M. (1997). Predictors of dating violence among high school students. Journal of Interpersonal Violence, 12, 546-568.

Paiva, C., \& Figueiredo, B. (2004). Abuso no relacionamento íntimo: Estudo de prevalência em jovens adultos portugueses. Psychologica, 36, 75-107.

Perista, H., Cardoso, A., Silva, M., \& Carrilho, P. (2012). Delinquência e violência juvenil em Portugal. Traçando um retrato a diferentes vozes. Lisboa: Centro de Estudos para a Intervenção Social. Retrieved from http://www.youprev.eu/ pdf/YouPrev_NationalReport_PT.pdf

Price, L., Byers, S., Sears, H., Whelan, J., \& Saint-Pierre, M. (2000). Dating violence amongst New Brunswick adolescents: A summary of two studies. New Brunswick: University of New Brunswick.

Raj, A., \& Silverman, J. (2002). Violence against immigrant women: The roles of culture, context, and legal immigrant status on intimate partner violence. Violence against Women, 8(3), 367398. doi: $10.1177 / 10778010222183107$

Ramos, M., Green, D., Booker, J., \& Nelson, A. (2011). Immigration status, acculturation, and dating violence risk for hispanic adolescent girls in New Mexico. Maternal and Child Health Journal, 15, 1076-1080. doi:10.1007/s10995-010-0653-0

Rohner, R. P., Khaleque, A., \& Cournoyer, D. E. (2005). Parental acceptance-rejection: Theory, methods, cross-cultural evidence, and implications. Ethos, 33(3), 299-334. doi: 10.1525/eth.2005.33.3.299

Rohner, R. (2005). Intimate partner acceptance-rejection/control questionnaire (ipar/cq): test manual. In R. P. Rohner, \& A. Khaleque (Eds.), Parental acceptance-rejection: Theory, methods, cross-cultural evidence, and implications (pp. 227242). Storrs: Rohner Research Publications.

Saavedra, R. (2011). Prevenir antes de remediar: Prevenção da violência nos relacionamentos íntimos juvenis (Tese de Doutorado). Universidade do Minho, Braga, Portugal.

SEF. (2014). Relatório de imigração, fronteiras e asilo, 2013. Lisboa: SEF. Retrieved from http://sefstat.sef.pt/Docs/ Rifa_2013.pdf

Silverman, J., Decker, M., \& Raj, A. (2007). Immigration-based disparities in adolescent girls' vulnerability to dating violence. Maternal and Child Health Journal, 11(1), 37-43. doi: 10.1007/ s10995-006-0130-y

Straus, M. (2004). Prevalence of violence against dating partners by male and female university students worldwide. Violence against Women, 10(7), 790-811. doi: 10.1177/1077801204265552

Support Unit for Migrant Victims and Victims and of Racial and Ethnical Discrimination. (2013). GAVUAVIDRE - Estatisticas da APAV 2013. Lisboa: APAV. Retrieved from http://apav.pt/ apav_v2/images/pdf/Estatisticas_UAVIDRE_2013.pdf

Swan, S. C., \& Snow, D. L. (2002). A typology of women's use of violence in intimate relationships. Violence against Women, 8, 286-319.

Teten, A., Ball, B., Valle, L., Noonan, R., \&, Rosenbluth, B. (2009). Considerations for the definition, measurement, consequences, and prevention of dating violence victimization among adolescent girls. Journal of Women's Health, 18(7), 923-927. doi:10.1089/jwh.2009.1515

Torres, J. G., Schumm, J. A., Weatherill, R. P., Taft, C. T., Cunningham, K. C., \& Murphy, C. M. (2012). Attitudinal correlates of physical and psychological aggression perpetration and victimization in dating relationships. Partner Abuse, 3, 76-83. doi:10.1891/1946-6560.3.1.76

Vagi, K. J., Rothman, E., Latzman, N. E., Tharp, A. T., Hall, D. M., \& Breiding, M. J. (2013). Beyond correlates: A review of risk and protective factors for adolescent dating violence perpetration. Journal of Youth and Adolescence, 42(4), 633-649. doi: 10.1007/s10964-013-9907-7 
Volz, A. (2007). Investigating the relational dynamics associated with adolescent dating violence: The roles or rejection sensitivity and relational insecurity (Doctoral dissertation). Miami University Oxford, Ohio, EUA.

Volz, A., \& Kerig, P. (2010). Relational dynamics associated with adolescent dating violence: the roles of rejection sensitivity and relational insecurity. Journal of Aggression, Maltreatment \& Trauma, 19, 587-602. doi: 10.1080/10926771.2010.502088

Williams, S. L., \& Frieze, I. H. (2005). Patterns of violent relationships, psychological distress, and marital satisfaction in a national sample of men and women. Sex Roles, 52, 771-784. doi: 10.1007/s11199-005-4198-4
Windle, M., \& Mrug, S. (2009). Cross-gender violence perpetration and victimization among early adolescents and associations with attitudes toward dating conflict. Journal of Youth Adolescence, 38, 429-439. doi: 10.1007/s10964-008-9328-1

Wekerle, C., \& Wolfe, D. (1999). Dating violence in midadolescence: Theory, significance, and emerging prevention initiatives. Clinical Psychology Review, 19(4), 435-456.

Yick, A. G. (2000). Predictors of physical spousal intimate violence in Chinese American families. Journal of Family Violence, $15,249-267$. 